\title{
Networking and innovation within the ornamental plant sector
}

\author{
Evelien Lambrecht ${ }^{1 *}$, Nicole Taragola ${ }^{2}$, Bianka Kühne ${ }^{1}$, Maarten Crivits $^{2}$ and Xavier Gellynck ${ }^{1}$
}

\author{
* Correspondence: \\ Evelien.Lambrecht@ugent.be \\ ${ }^{1}$ Ghent University, Faculty of \\ Bioscience Engineering, Department \\ of Agricultural Economics, Coupure \\ Links 653, 9000 Ghent, Belgium \\ Full list of author information is \\ available at the end of the article
}

\begin{abstract}
The ornamental plant cultivation could benefit from networking, as the locus of innovation is no longer the individual farm, but increasingly the network within which the farm is embedded. The main contribution of this paper is to shed light on the relation between networking and innovation and the influencing factors for networking as leverage for innovation within the ornamental plant sector. In contrast to the majority of the innovation studies, which are focusing on technological innovation i.e. product and process innovations, this study includes also marketing and organizational innovations. By looking at the link between innovation type and network partner, we found that network partners differ depending on the innovation type. Furthermore, this study provides insights into the factors influencing networking in the ornamental plant sector in particular. The results lead to implications for ornamental plant growers and network coordinators. It is important that growers are aware of the merit of partner suitability for the innovation type they are aiming at. For network coordinators, it is important to set up a clear strategy and communicate for which innovations their network can advise and help the farmer. They could focus on improving their approachability and try to increase the added value of activities by aligning them better with farmers' needs.
\end{abstract}

Keywords: Innovation types; Network partners; Ornamental plant production; Qualitative research; Flanders (Belgium)

\section{Background}

For farmers and horticultural growers, as for entrepreneurs in general, innovation is widely recognized as an important strategic tool to increase the competitive advantage of their companies (Diederen et al. 2003; Gellynck et al. 2007; Knudson et al. 2004), resulting in a better financial as well as sustainability performance (Bos-Brouwers 2010; Gronum et al. 2012). In this paper, we focus on ornamental plant cultivation in Flanders (Northern Belgium), mainly consisting of micro-sized ( $<10$ employees ) and family owned businesses, characterized by strong individualism (Van Lierde et al. 2011). The sector was flourishing during the sixties. From the seventies on however, it encountered an increasing competition from the Netherlands and later on from the rise of ornamental plant cultivation in South-America and Africa. In 1973, the world's first oil crisis confronted glasshouses, and hence a big part of the ornamental plant sector, with high energy prices resulting in a reduced profitability. Since then, several energy crises followed, and the sector was confronted with important changes in the 
competitive environment (Van Lierde et al. 2011). In addition, during last decades, there was a growing request for environmentally and socially legitimate production (Taragola et al. 2002b; Van Lierde et al. 2009). Despite the importance of innovation to respond to these external changes, ornamental plant growers, in common with other small and medium sized enterprises (SMEs), face problems in developing and implementing innovations (Taragola 2003; Taragola et al. 2002a; Van Lierde et al. 2011). In this paper, we aim to elucidate these challenges from a networking perspective.

From the perspective of SMEs that often have limited resources, the establishment of network relations can provide an avenue to address innovation problems (Lasagni 2012; Pittaway et al. 2004).

Networks give SMEs access to complementary resources, skills, capabilities, and knowledge that are not internally available (Døving and Gooderham 2008; Pittaway et al. 2004). In order to achieve innovation, a wide range of network partners can be used, such as colleagues, input industries, traders, researchers, extensionists, government officials, civil society organisations, etc. Managing and developing dynamic networks is an important requisite for entrepreneurial success (Gibb 1997). For SMEs, however, it is often less straightforward to identify the appropriate network partners to get access to the required inputs in the innovation process. Moreover, they often get locked into established networks of relationships and struggle to break out of these relationships and build new ones (Birkinshaw et al. 2007). The scarcity of resources and the complex entrepreneurial environment, make it necessary for SMEs to actively select the appropriate network partners according to the required innovation type (Lipparini and Sobrero 1994; Ritter and Gemünden 2003; Pittaway et al. 2004). However, studies investigating the appropriateness of network partners in relation to different innovation types are scarce and need far more research attention (de Man and Duysters 2005; Howells et al. 2004; Varis and Littunen 2010). In addition, most of the existing studies focus much more on technological process innovations and product innovations than on non-technological and intangible ones, i.e. marketing and organizational innovations. There are nonetheless strong reasons to use a comprehensive innovation concept and give more attention to non-technological and intangible kinds of innovations (Birkinshaw et al. 2008; Pittaway et al. 2004; van Galen and Verstegen 2008; Damanpour and Aravind 2012; Crossan and Apaydin 2010). In our paper this research gap is addressed for the sector of ornamental plant cultivation, by examining the network activities depending on the type of innovation, and the factors influencing the networking decisions.

The remainder of this paper is structured as follows: The conceptual framework is presented in the second part. In section three the methodology is described, followed by the results and discussion. Finally, conclusions are drawn, and research related and managerial implications are provided, followed by the limitations of the study and possibilities for further research.

\section{Conceptual framework}

In Figure 1, the key elements of this paper - innovation and networking - are situated within the conceptual framework, accompanied by the research objective. Furthermore, a definition of both terms is provided below. Innovation is defined as an ongoing process of learning, searching and exploring, resulting in new products, new processes, 


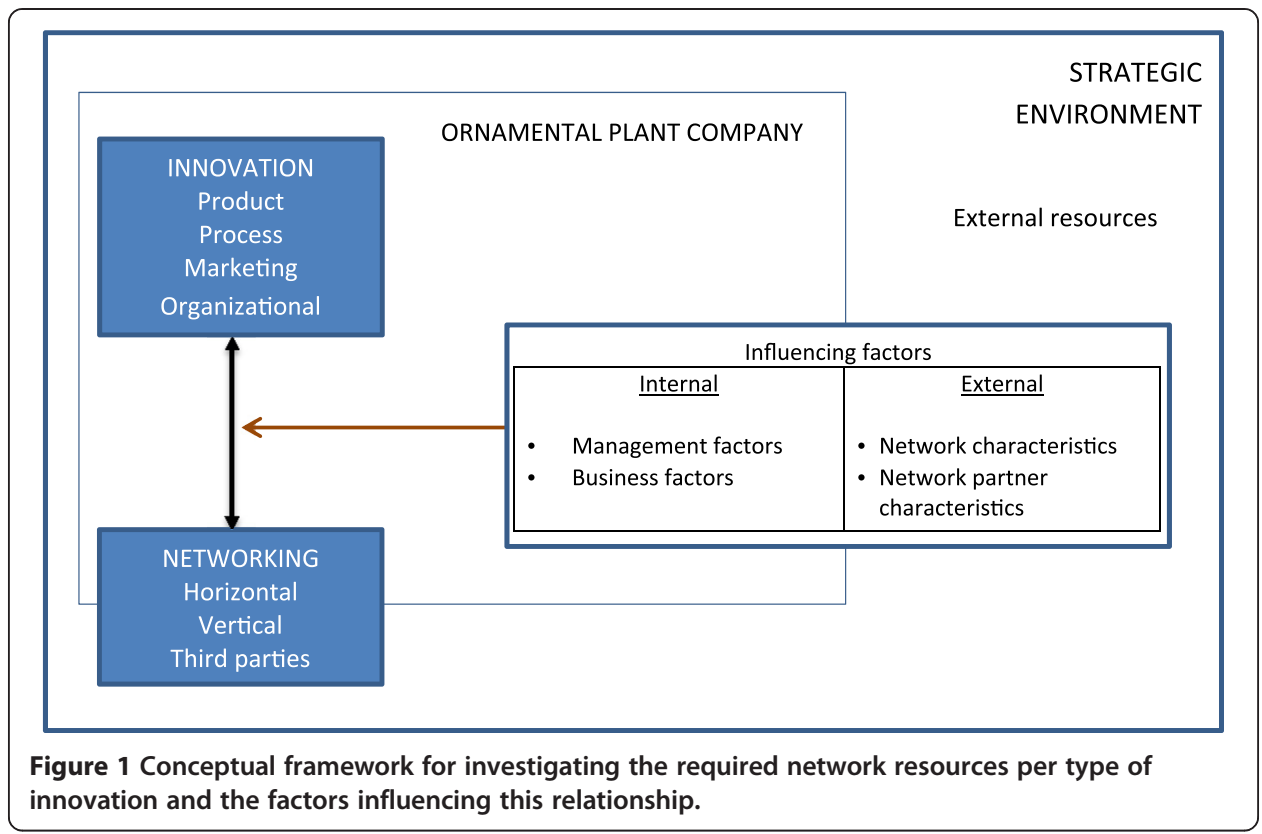

new forms of organization and marketing methods (Lundvall 1995). Hereby, product innovation is defined as the introduction of a good or service that is new or significantly improved with respect to its characteristics or intended uses; process innovation as the implementation of a new or significantly improved production or delivery method; marketing innovation as the implementation of a new marketing method involving significant changes in product design or packaging, product placement, product promotion or pricing and finally organizational innovation as the implementation of a new organizational method in the firm's business practices, workplace organization or external relations (Eurostat 2005). Networking is defined as the establishment of relations that give SMEs access to complementary resources, skills, capabilities, and knowledge that are not internally available (Pittaway et al. 2004). The networks used can be divided into three major categories or types: horizontal and vertical networks as well as collaboration with third parties (Kühne et al. 2010). Horizontal networks consist of firms belonging to the same industry, thus being primarily competitors or peers. Competitors are likely to be contacted to share common problems that are outside the competitor's area of influence - for instance a regulatory change (Tether 2002). It has become accepted that horizontal collaboration among SMEs can speed up product development (Winch and Bianchi 2006; Morris et al. 2007). However, it comes at risk of technology leakage to rivals and a loss of control over the innovative process (Ritala and Hurmelinna-Laukkanen 2012). From an empirical perspective, some studies have found a positive correlation between horizontal collaboration and innovation (Quintana-Garcia and Benavides-Velasco 2004; Najib and Kiminami 2011), while others did not find any evidence that horizontal collaboration was significant explaining innovation among SMEs (De Propris 2002; Freel and Harrison 2006).

Vertical networks are composed of different partners of the chain involved in all upstream and downstream flows of products, services, finances, and information. The vertical network includes all organizations from the direct chain (supplier, manufacturer, 
customer) to the extended chain (suppliers of suppliers and customers of customers) (Vorst 2000; Mentzer et al. 2001). It allows a firm to gain considerable knowledge about new technologies, markets and process improvements (Whitley 2002) and has a significant impact on the successful implementation of product innovations (Miotti and Sachwald 2003; Nieto and Santamaria 2007; Tether 2002; Nieto and Santamaria 2010). A recent study of Lasagni (2012) for example finds co-operation with both buyers and suppliers being positively significant in aiding innovation. Third parties are persons or entities other than chain members or peers, such as consultants, research institutes, financial providers, etc. Consultants sensitize companies for possible improvements in existing processes and assist them in identifying weaknesses (Gemünden et al. 1996). Several studies have documented the important role that universities and other research institutions have on innovations for which fundamental scientific knowledge is needed (Bozeman 2000; Vuola and Hameri 2006; Robin and Schubert 2013).

Networking is an important leverage for innovation in SMEs (Lasagni 2012; Pittaway et al. 2004; Zeng et al. 2010), but can be hampered or facilitated by numerous factors, which can be internal or external to the company (De Groot 2003; Hoffmann and Schlosser 2001; Kaufmann and Tödtling 2002; Van Gils and Zwart 2004). Internal factors can be divided into management and business factors. Management factors are related to the biographical (e.g. age, education level) and social characteristics (e.g. personal values, attitudes, objectives) of the firm manager and his/her management processes (e.g. strategic vision, decision making and planning processes). Business factors are related to the size/structure of the company, the available human resources, the financial situation, etc. Typical for SMEs are, for example, the small number of employees that are able to act as nodes establishing and maintaining links to innovation networks. This restricts the potential to search for and collect innovation-related information and to collaborate in cooperative innovation projects. This often results in a lack of experienced employees as well as a lack of time to set up relations with innovation partners, due to routine and administrative work (Kaufmann and Tödtling 2002; Taragola et al. 2004).

External factors belong to the company's strategic environment. In the paper we focus on the network characteristics and network partner characteristics, including for example the presence/absence or willingness of partners to cooperate with and the lack of responsiveness of knowledge providers (e.g. researchers) because they are often rather 'supply driven' than 'demand driven' (Katz and Barandun 2002; Byerlee et al. 2002). Studies on these aspects are scarce on the level of farms (e.g. Klerkx et al. 2010) and ornamental plant companies in particular. As there are indications in literature that network partners consulted are related to the type of innovation, the influencing factors for networking that are related to the network partners consulted are also expected be related to the innovation type.

\section{Methods}

A qualitative research methodology is used, which is suitable for gaining an understanding of decision making in SMEs (Hill and Wright, 2001), and networking in particular (O'Donnell and Cummins 1999). Based on the specific aims of this research, between June 2011 and March 2013, we conducted twenty in-depth interviews and two focus group discussions with nine growers in total. Both methods assemble detailed 
attitudinal and experiential information from the respondents by using open-ended, exploratory questions in a semi-structured way (Powell and Single 1996). While focus groups can reveal a greater variety of views, opinions and experiences, during in-depth interviews the interviewer is probing the respondent more deeply to uncover underlying motivations, beliefs, attitudes and feelings on a topic (Hennink 2007; Malhotra 1999). Hence, with both techniques a broad overview and comparatively rich qualitative data can be assembled (Fein et al. 1997).

Interview guides based on a comprehensive literature review were pilot-tested prior to the interviews and focus groups and adapted accordingly. The interview guide consisted of the following four parts:

(a) Generic section about profile, background and company characteristics

(b) Innovation and innovation capacity

(c) Social relationships and networks

(d) Knowledge for innovation through networks

Data were collected from growers and network coordinators active in the Flemish ornamental plant sector. In total, fourteen ornamental plant growers were interviewed, including five that were also network coordinators. Additionally, six interviews were conducted with exclusively network coordinators. All respondents were first contacted by telephone to introduce the aim of the study and to arrange an appointment. The interviews were conducted at the respondents' place so they would feel more at ease and took one to two hours per respondent. All interviews were undertaken by the same interviewer in order to exclude interviewer bias. For the focus groups, the assignment of the growers to the two groups (five and four growers respectively) was based on their network activity (high-low), as determined by experts from the local research centre for ornamental plants. This offered the respondents the possibility to discuss in homogeneous groups. For the focus groups, the interview guide was slightly adapted. All interviews and focus groups were recorded and transcribed. The data were sorted and coded using NVIVO 10. The innovations implemented were categorized in product, process, marketing or organizational innovations. The possible network partners were coded according to three network categories and further refined into subcategories (cf. infra:). Furthermore, the perceived influencing factors for networking were divided into internal and external factors. The codes of the second sublevel were based on common similar words, concepts or themes. These codes were discussed with other researchers of the project consortium and further refined into the current analytical categories, as discussed in the result section. Via matrix coding queries, we identified the network partners used and the factors influencing the networking behaviour per type of innovation.

\section{Results}

Before identifying the role of networking in the development and implementation of the different types of innovations and the influencing factors (see What is the contribution of the network to the development and implementation of the different types of innovation (a) and What factors influence this relationship (b)?), it is necessary to have an insight into the innovations applied within the sector (see What types of innovations 
are applied?) and the network activities in which the ornamental plant growers are involved (see What types of networks are used?). In the following paragraphs, the findings on these aspects are formulated.

\section{What types of innovations are applied?}

When asked for their perception on innovation, mainly product and process innovations were reported by the respondents. Only some of them spontaneously mentioned marketing and organizational innovations as well. Afterwards, we formulated our definition of innovation: "Product, process, marketing and organizational innovations which are new to firm or sector, ranging from incremental to radical innovation", ensuring that everyone was talking about the same. The innovations mentioned were those already implemented or likely to be implemented by the respondents in the near future.

Table 1 gives an overview of the mentioned innovations by type.

\section{What types of networks are used?}

The networks used are divided into three major categories: horizontal and vertical networks as well as collaboration with third parties (Kühne et al, 2010). Horizontal networks include formal and informal networks with peers inside as well as outside the sector. With respect to the vertical networks, we observed that collaboration of growers is often better with suppliers than with customers, due to the stronger bargaining power of the latter. Third parties include persons or entities which are other than peers or the chain, such as public administration, research institutes, consultants, innovation support centres, financial providers, etc. Noteworthy is the Think-tank "Ornamental Plant Strategy 2020", which is established by the Flemish Government some years ago as a public-private partnership, with the mission to formulate strategies and actions for the future, and formulate policy recommendations.

What is the contribution of the network to the development and implementation of the different types of innovation (a) and what factors influence this relationship (b)?

Firstly, we focus on innovation in general, referring to aspects found to be valid for all types of innovation. Afterwards, we focus on the four different types of innovation separately, as the network types used depend significantly on the type of innovation. This is shown in Table 2, which gives an overview of the network partners consulted per type of innovation.

Table 1 Innovation in ornamental plant production by type

\begin{tabular}{ll}
\hline Product innovation & $\begin{array}{l}\text { New product-/pot size; New product variety; Selling flowering plants instead of plants } \\
\text { in bud; Switch to less energy intensive plants }\end{array}$ \\
$\begin{array}{l}\text { Process innovation } \\
\text { Robotization; New cultivation method; Water recycling; Expansion; New technical } \\
\text { solutions to improve quality; Installation of cogeneration engine, solar panels; New } \\
\text { fertilization techniques; Alternative control of pests/diseases }\end{array}$ \\
$\begin{array}{l}\text { Own label; New packaging; Establishment web shop; Self-service field with cut flowers; } \\
\text { innovation }\end{array}$ \\
$\begin{array}{l}\text { Organizational } \\
\text { innovation }\end{array}$ & $\begin{array}{l}\text { Move labor intensive tasks to low wage countries; Hire East-European labor forces; Elim- } \\
\text { ination of links in the chain; Establishment of close collaboration with colleagues and/ } \\
\text { or chain partners to fulfill market needs; Joint product development; Formation of a } \\
\text { joint research network; New establishment; Introduction of a new software system }\end{array}$ \\
\hline
\end{tabular}


Table 2 Networks partners consulted per type of innovation

\begin{tabular}{|c|c|c|c|c|c|}
\hline & Consulted partner & Product & Process & Marketing & Organizational \\
\hline Horizontal & Colleagues & & $x$ & $x$ & $x$ \\
\hline \multirow[t]{5}{*}{ (PEERS) } & Home & & $x$ & $x$ & $x$ \\
\hline & Abroad & & $x$ & $x$ & $x$ \\
\hline & Other sector & & & & $x$ \\
\hline & Producer organization & $x$ & $x$ & & \\
\hline & Business club & & & & $x$ \\
\hline Vertical & Suppliers & $x$ & $x$ & & $x$ \\
\hline \multirow[t]{8}{*}{ (CHAIN) } & Equipment & $x$ & $x$ & & $x$ \\
\hline & Seeds/young plants & & $x$ & & $x$ \\
\hline & Phyto-products & & $x$ & & $x$ \\
\hline & Fertilizer & & $x$ & & $x$ \\
\hline & Buyers & $x$ & & $x$ & \\
\hline & Auction & $x$ & & $x$ & \\
\hline & Wholesaler/trader/exporter & $x$ & & $x$ & \\
\hline & End consumer & $x$ & & $x$ & \\
\hline \multirow[t]{7}{*}{ Third parties } & Public administration & & $x$ & & $x$ \\
\hline & Research institutes/universities & $x$ & $x$ & & \\
\hline & Consultants/advisor & & $x$ & $x$ & $x$ \\
\hline & Producer association (extension) & & $x$ & & \\
\hline & Innovation support centres & & $x$ & & $x$ \\
\hline & Financial providers & $x$ & $x$ & $x$ & $x$ \\
\hline & Think tank & & & & $x$ \\
\hline
\end{tabular}

With regard to the influencing factors, internal as well as external factors are determined. We found that the internal influencing factors were valid for all types of innovation, while the external influencing factors are also largely dependent on the type of innovation, as they are often related to the network used.

Innovation in general

a) Contribution of network to innovation In general our respondents perceive the outcomes of network participation as beneficial to capture ideas, reduce distance with policy makers, prevent them from insulation, know the right people and places to obtain information from inside as well as outside the horticultural sector. Further advantages mentioned, were the possibility to exchange knowledge with colleagues and the higher awareness of upcoming events and new important trends. Overall, networking is perceived as an important strategic tool in attaining innovation: "You have to come out, I'm sure about that. In my opinion, networking is very important for innovation" (farmer interview).

b) Influencing factors We found that the internal influencing factors are valid for all the types of innovations. An important internal factor with a negative impact on networking is the lack of human resources, including problems in terms of networking skills and a lack of entrepreneurial spirit of the growers: "The number of growers is diminishing in the ornamental plant sector, and so does the entrepreneurial spirit. 
Growers don't see the need to attend network activities anymore [...]. Your future is not made when attending a network activity, but the penny has to be dropped in order that you can start thinking about your own operations" (farmer interview). The size and structure of the companies are also internal factors which influence the network activity of the growers. Not all the companies are structured in a way that the managers or employees are able to leave the farm to attend a network activity: "If I'm not here, the production can't continue" (farmer interview). Furthermore, growers are not always open towards new ideas and change, nor willing to share information. Another observed internal factor with a negative impact on networking is related to a bad financial situation of the grower, resulting in fear to communicate with colleagues and the tendency to isolate themselves on the farm: "It doesn't go well within the sector. In such situations, people feel less like leaving their farm" (focus group).

As the external influencing factors are in a large extent related to the type of innovations, they will be discussed in the following paragraphs.

\section{Product innovation}

a) Contribution of network to innovation For product innovation, the vertical relationships with suppliers and buyers are important. Seed and plant suppliers develop products responding to market demands and only contact growers in the final stage of market implementation. One farmer explains how he sees product innovation in the sector: "We are constantly looking for new breeds. In fact, that is not our task, the supplier does this. Every year, they try thousand new breeds, of which four or five are good to try on small scale in their company. After several years of trying, they look for growers who are willing to grow products on a larger scale. We often try them and if they are $O K$, next year, they are in their catalogue" (farmer interview).

During the last years, there has also been a collaboration project with research institutes to develop new races. This can be on an individual basis, or via a producer organization: "When talking about product innovations and improvement of breeds, we mostly collaborate with research centres such as ILVO (The Institute for Agricultural and Fisheries Research. For more information: http://www.ilvo.vlaanderen.be/) and PCS (Research centre for ornamental plants. For more information: http://www. pcsierteelt.be/)' (farmer interview). Flemish examples of producer associations are AZANOVA and BEST-select, representing respectively 21 progressive azalea growers and 20 tree nursery growers, working together with ILVO to develop market oriented product innovations.

b) Influencing factors Having a good relationship with buyers is clearly perceived as a factor positively influencing product innovation. The following grower specifies his close relationship: "I have several buyers with whom I have a very good relationship, who are open for innovation and who are critical. That is what we need. We do not call each other on a daily basis, but we have good contact. Not everything that we produce is fantastic, so they have to inform us about things which can be improved, in order that we can think about it, and do suggestions for improvement" (farmer interview).

Attending exhibitions significantly increases the contact with the buyers: "Every month, we exhibit at the fair in Flanders Expo. The exporters come to us, together with their 
foreign clients. The majority of them know me personally which I consider as very important to have a good feeling with my buyers" (farmer interview). Also a good contact with traders is important for product innovations. "They serve us with ideas and are stimulating us to cultivate new races" (farmer interview). A good relationship with the exporters is crucial: "Several exporters talk with us, and by talking, they know you, and do an extra effort to sell your products. If something is wrong with my products, I prefer that they inform us, and that they not just go to another producer" (farmer interview).

For producer organizations collaborating for product innovation, competition among colleagues can be an important hindering factor: "Within the group [AZANOVA], I often perceive farmers shielding off their company. They join, do not say anything, and give no input, which disturbs the group dynamics. They say nothing, and in the end, if a decision will be made, they are suddenly against the decision. If we would be more open with colleagues, it would be easier" (farmer interview).

A farmer not participating in the aforementioned producer organization mentioned that he would prefer to invest a bigger amount, but with a smaller number of growers. According to him: "it is impossible to form a strong group, if you see all the members, and how they counteract each other" (farmer interview).

\section{Process innovation}

a) Contribution of network to innovation For process innovations, growers can rely on a wide variety of networks, mostly within their sector. It is crucial to note that when growers aim to improve their own production process, they have to know the alternative processes, materials and equipment to be potentially used. Colleagues are an important partner to exchange this kind of information. These encounters often occur on an informal basis, for instance after the official part of an organized network activity by a third party such as a sector association, research institute or consultant. The network coordinator of Sietinet (A network established and coordinated by ILVO in cooperation with eight other Flemish research institutes with the aim to improve the translation and transfer of research results to the ornamental plant sector. The network was funded by the government from 2004 to 2012, and currently continues its operation as a 'Sietinet community') for example observed how a lot of new ideas come up when people "stay and talk".

Also contacts with equipment suppliers are considered as fruitful: "We sat together several times with the installers of the potting machine. We were discussing and puzzling a lot" (farmer interview).

A lot of ideas for process innovations are also obtained via input suppliers (e.g. seeds, young plants, phyto-products and fertilizers). Moreover, extension services, offered by paid consultants or public administrations and research institutions, guide growers in their process innovations. The practical based research institutes, which mostly focus on short term results, are preferred among the Flemish growers. The universities, which focus on basic and long-term research, are less used for process innovations than for product innovations. Also producer associations and more specifically the ICARD (Innovation Centre for Agricultural and Rural Development ) play an important role in this matter: "Because that [ICARD] is actually a player who brings together various parties to support the innovation process" (focus group).

Furthermore, financial providers provide the necessary funds, while public administrations are contacted when applying for investment subsidies. 
b) Influencing factors Similar as for product innovations, competitive behaviour negatively influences the possibility of networks to contribute to process innovations. Remarkable is the reluctance to share information with colleagues. With regard to process innovation, it is particularly the fear of a competitor taking over one's acquired 'stock of knowledge' that plays a role. As one farmer expressed: "If I found a good way of working, nobody should have a look at it!" or also: "We do the seed treatment all by ourselves. That is something that requires years of knowledge and expertise, and it should not just be exhibited" (farmer interviews).

An important factor negatively influencing cooperation with suppliers of equipment is the impossibility to find a suitable partner: "We contacted a number of companies, and asked them to put some prototypes on paper, but none met our expectations, so we continued to work manually" (farmer interview).

Concerning the network activities organized by third parties, which are mostly used for process innovations, a negative influencing factor is the low perceived added value. Respondents mentioned that the same topic is too often returning on different events: "For example, the study day of this year and the one of last year, they were the same. They now started with research about IPM (Integrated Pest Management) and be sure, it will be the same for the coming two-three years, IPM again and again" (focus group).

Another important hindering factor for networking with third parties such as public administration, research institutions, universities, etc. is that the threshold to contact them is often too high. Additionally, the restricted focus on more policy related topics (e.g. IPM) is often not highly appreciated and might lead to a sceptic attitude towards government and third parties. As one network coordinator states: "One of the things that play a role is the fact that growers are very distrustful of the government. Because the government signifies tax, law, obligations, etc., and that all costs money" (network coordinator). Moreover, as growers' problems and hence the required information is considered to be very company specific, they spend a lot of time listening to less relevant information: "Everyone should look for information responding to his proper needs" (farmer interview). Additionally, growers state that they are often not aware of organized activities:

- Respondent 1: "I think that a lot of information is not properly communicated with the sector. Let's say the tour that will be organized at the potting compost firm next week, and the visit to the coal-heater within two weeks, are you aware of that?" Respondent 2: "No" Respondent 3: "How do you know that?" Respondent 2: "And who organizes that?” (focus group)

- "They [ICARD] did not announce it properly. [...] I think they should announce their activities better. There are enough membership lists etc..." (farmer interview).

With regard to the networking with research institutes, recent initiatives of collaboration with growers, such as Sietinet, have proven to be successful: "We now have much more contact with research centres than before. The idea of the professor in the university, the tower, the threshold, is slightly disappearing. During workshops, farmers have the possibilities to have a chat with researchers" (farmer interview). However, the recent withdrawal of public funding for Sietinet is seen as a problem: "The government 
wants to encourage networking, but now that there is a successful network, funding stops" (farmer interview).

The unique cooperation between fundamental and practice based research centres and the growers is perceived as a positive factor: "Research institutes work closely together, much better than in neighbouring countries. For example, two weeks ago, I attended the royal horticultural society, a conference for the whole world. There, ILVO was talking about a boxwood disease. This shows that we are much further than others. That's through the unique combination between scientific and practical based research and us, who cooperate as a producer organization" (farmer interview).

Some growers do have the opinion that research is too much driven by government programs, such as the increasing demands in terms of sustainability (cf. supra), imposing stringent and costly requirements on the growers: "The growers say to the research institutions: you get money from the government to conduct research on sustainable farming, which increases our costs. And sometimes this creates a tension"; "You should not help them [the research institutions] too much, because if they invent something new you have to apply it, which increases our costs" (farmer interview).

Private consultants make an important contribution to process innovations, since they can deliver tailored advice. For many growers this type of advice is preferred, since their problems and hence their required information is very company specific. A disadvantage could be that network activities are neglected, because they count on their consultant to attend such activities: "And effectively, it may be true that some people do not go to meetings, because they think I am attending them" (consultant). On the other hand, an interviewed consultant mentions the high level of participation and recognition for his annual networking event, which is in the words of a farmer "short, to the point, and solid" (farmer interview).

The ICARD, founded several years ago by a producer association, is too little known among the ornamental plant growers. Also, growers who know the organization are not always aware of the added value: "Yes, we know this organization, but at that time I did not think they could tell me something extra"; "I do not know if this is really used and appreciated" (focus group and farmer interview).

The value of networking with other sectors, both within and outside agriculture, is hardly recognized by a large part of the growers: "We already know most of our crop. If something is organized on a different kind of crop, we think that this will not be interesting for us" (focus group). This citation also shows that many growers mainly think production-oriented.

\section{Marketing innovation}

a) Contribution of network to innovation The introduction and success of marketing innovations is perceived as a difficult process: "Innovation is important, but it is not easy to place a new product into the market. It's a long way, a very hard road. Market innovation is much harder than product innovation". Networking with colleagues home and abroad can facilitate marketing innovation, for example, a grower introduced a self-service field with cut-flowers. He "discovered the idea with a colleague who offers similar services" (farmer interview). To obtain more information, he went to Germany, where a colleague-farmer owns several fields. "He [other farmer] gives advice with respect to technical topics and selection of breeds" (farmer interview). Furthermore, 
several collaborative initiatives are set up to market the plants. There is for example 'BE.plants', a collaboration of five Belgian growers of garden plants: "We are no competitors, but we complement each other well so that we can offer a good mix of plants, can assure delivery continuity, and the collaboration enables the exhibition of our products at fairs as we can share the exhibition costs' (farmer interview). This gives the growers access to each other's networks, makes the group more visible and leads to competitive advantage for all the members.

Being aware of consumer needs is an important factor for marketing innovations. For this, vertical networks, mainly with buyers such as wholesalers, traders and endconsumers, can also provide new ideas for farmers which can be transformed into marketing innovation. "Going to see and listen to buyers is very important, asking whether they see or expect changes" (farmer interview). To this regard, participation in international trade fairs may be of interest. Also a yearly international study tour of the ornamental plant growers, organized by a government consultant, proved to provide significant insight into international consumer demands. Paid consultants can also be a fruitful source for ideas with respect to marketing innovations: 'I go to customers of my customers inland and abroad to identify their requirements with respect to packages, pot sizes, varieties and to follow up market evolutions' (network coordinator interview - consultant). Finally the ICARD is offering services in the field of marketing innovation.

b) Influencing factors As with other types of innovation, distrust between colleagues hinders marketing innovation: "Everyone does his best for himself". Here, a particular concern is related to the preservation of the company identity: "A couple of years ago, I had the idea to bring all the producers of our product together and to promote the product instead of the individual companies. At the time we would design the logo, two factors hindered this: First, growers had their own logo and did not want to replace it and second, they did not want to pay for it. You increasingly feel that companies have their own strategy to reach the market, and are decreasingly interested in promotion of the product" (farmer interview).

With respect to vertical networks, problems arise when chain members do not consider each other as potential partners for collaboration. Perceived conflicts of interest sustain the disbelief that collaboration efforts would deliver greater benefits for all chain members: "Mostly, wholesalers are not prepared to work together on a respectful basis with the growers" (farmer interview). Also, strategic visions on innovation often differ between chain members. For example in the stage of the implementation of a product, all chain partners have to be involved and convinced about the advantages. This often seems to be difficult: "Developing a new product is a long process, but the marketing of it is even a harder way. First, breeders have to accept it, second the retailer and then the end-consumer" (farmer interview).

Good communication between the actors within the chain is an important factor stimulating marketing innovation. "We [plant propagators] observe that growers are not very creative, thus we try to look for creative solutions for them and introduce them in the chain. We do some marketing experiments with new colours, other pot sizes, you name it... a good communication with the breeder and the growers is hence crucial" (farmer interview). 
As mentioned above, international trade fairs can be important in order to become aware of consumer needs. However, for some growers participation to these fairs has become too expensive: "We used to participate in almost every fair, but nowadays that costs so much money that we limit ourselves to the most important fairs" (farmer interview). Cooperation with colleagues can be an option to share these costs.

\section{Organizational innovation}

a) Contribution of network to innovation Organizational innovations often concern several domains of the company, implying ample decisions to be made. For this reason, it is important to have adequate knowledge with respect to the different domains. A combination of networking with horizontal and vertical networks as well as with third parties seems to have a huge influence on the success of organizational innovations and is hence advised. People with access to a lot of contacts, are able to build up a larger knowledge base (Pittaway et al. 2004).

For organizational innovation, it is observed that contacts with people from outside the sector are often much more important than for other types of innovations. Next to the traditional networks in the horticultural sector, cross-sectoral networks such as business clubs where employers of different sectors can meet each other play a significant role in this type of innovation. Those contacts and conversations are fruitful and inspiring for issues related to generic business management: "I learn much more from companies outside the sector, although you don't see immediately the link with our activities, but on the level of generic business management such as marketing, financial and business planning, logistics, I never consult our own sector" (farmer interview). Other sources of learning about general business management are mainly expert advisors or consultants such as accountants. Also innovation support centres can play a role in supporting organizational innovation. With regard to organizational innovation, the think tank "Ornamental Plant Strategy 2020" is an important network at sector level.

b) Influencing factors A factor hindering networking for organizational innovations is the high threshold to connect with colleagues from outside the sector: "I am a chatterbox, but still... You are standing there [business club]. This is very difficult. You are standing there on your own at the bar. [...] Then, you hope that you'll meet someone who can form a link, but sometimes, it is like dying. I don't know, but personally, this is not always easy for me" (farmer interview). Also it takes time to get to know these people better: "You can't just say to a stranger, hey I am [name] from [company], can you tell me more about the organization of your company? It's not working in this way. You need to know those people, and this takes time. This is quite a task for me". A bottleneck is that despite the advantages, some growers don't see the utility to engage in business clubs.

Another factor that can hinder networking for organizational innovations is the difficulty to apply the lessons learnt in the own company: "A lot of theories are used, but the practical implication is another story" (farmer interview). Because of these difficulties, some growers prefer to exchange management experiences with their own colleagues, although these contacts are usually limited. 
Respondent: "Especially when it comes to management, I find it more useful to speak to another grower who is doing well".

Interviewer: "And do you have many of such contacts?"

Respondent: "I have some of these counsellors, or how I call it, but still too few".

With regard to cooperation with other colleagues in terms of organization, some growers are afraid of losing their freedom: "I am not in favour of group buying, because I also have to give up my freedom" (farmer interview). The individualism of the growers is an important obstacle for cooperation among colleagues: "We did not expect much from cooperation in the field of logistics and that individualism is more common in the tree nursery sector than for example in the glasshouse vegetable sector" (farmer interview).

Third parties can play an important role in supporting organizational innovations, but here also a number of bottlenecks are reported. Organized network activities mainly focus on product or process innovation, while financial or organizational aspects are neglected: "It's been a long time since there was a meeting on financial aspects" (focus group).

Consultants often do have a lack of knowledge on organizational innovations. Availability of the required expertise is an important factor determining whether or not a grower appeals to a consultant for supporting organizational innovations: "This man has a lot of expertise within our sector, a real enrichment and he is so passionate about his job. He is guiding two collaborative networks. This is so fantastic. And also the relationships he built up during his career" (farmer interview).

Also limited awareness of the existence of certain organizations, such as the innovation support centres, which can support organizational innovations, is a limiting factor.

In short, we can say that the network partners consulted are dependent on the type of innovation. Furthermore, it was found that internal influencing factors are valid for all types of innovation, while the external ones are also related to the innovation type. In the following paragraph, the main findings are summarized and confronted with existing literature.

\section{Discussion}

This paper investigated the role of networking in the development and implementation of different types of innovation in the ornamental plant sector. Furthermore, the influencing factors for networking were identified. Therefore, a twofold research question was formulated: 'What is the role of networking in the development and implementation of innovations and what factors influence this relationship?'. The qualitative research methodology used, based on in-depth interviews and focus group discussions, is found to be suitable to gain a better understanding of the examined topic. Overall, networking is perceived as an important strategic tool to come to innovation in the sector. It can be hampered or facilitated by numerous factors. We observed that the networks used by ornamental plant growers are to a high extent dependent on the type of innovation, as also was the case with other SMEs (Ritter and Gemünden 2004).

The external influencing factors, which are linked to the strategic environment, were largely related to the type of innovation. The internal factors, however, were mostly valid for all types of innovation.

Internal factors negatively influencing the relationship between networking and innovation are a lack of human resources, including problems in terms of networking 
skills and a lack of entrepreneurial spirit. Furthermore, growers are not always open toward new ideas and change and willing to share information, especially when the economic situation is bad. The size and structure of the companies can also form a hindering factor related to the inability of managers or employees to leave the company to attend a network activity. Understanding these internal limiting factors, which can be generalized for small enterprises in general (e.g. Kaufmann and Tödtling 2002), is of great importance for network coordinators.

For product innovations, horizontal collaboration is found to be hardly important. Also in SMEs in general, this type of collaboration does not seem to be the most appropriate mechanism to achieve product innovations (Bayona et al. 2001; Nieto and Santamaria 2007). On the opposite, our study indicates that vertical collaboration (with suppliers and buyers) is very important for product innovations. Collaboration with suppliers enables a firm to reduce the risks and lead times of product development, while enhancing flexibility, product quality and market adaptability (Chung and Kim 2003). Furthermore, there is strong evidence that getting market information from buyers, and, in some cases, direct involvement between buyers and firms leads to more successful new product development (Atuahene-Gima 1995; Souder et al. 1997).

Research institutes seem to have a positive influence on product innovations, which can be related to the presence of fundamental knowledge in plant breeding. Factors with a negative influence on the relationship between networking and product innovation are the lack of trust between the chain partners and the high threshold of research institutes. However, recent collaboration initiatives with research institutes with the aim of product innovation proved to be successful and should be further encouraged in the future.

With regard to process innovations, the vertical network also plays an important role. Suppliers actively bring new ideas or provide equipment to the farms to develop better production facilities, reduce production costs or decrease processing time. This is not always a linear process, as often new machines are developed in collaboration with growers. Next to the vertical network, farmers frequently consult horizontal networks during the development of process innovations. Consultants are also perceived as important sources of information and knowledge for process innovation. They provide fundamental scientific or technological knowledge, but more commonly provide applied knowledge, specialist skills and information. Furthermore, research institutes and universities were found as partners for process innovations. The results reveal that the universities, which focus on basic and long-term research, are less used for process innovations than for product innovations in the ornamental plant sector. This was also the case in SME research (Robin and Schubert 2013).

The competition and distrust between colleagues is a factor hindering networking for process innovation. However, collaboration with colleagues-competitors needs not to be (directly) competitive. Farmers can collaborate when they face common problems and especially where these problems are seen as being outside the realms of competition and/or when by collaborating they can influence the nature of the regulatory environment, which is an important influencing factor for process innovations. Farmers also often collaborate with each other when they are not direct competitors of each other. For example, when they produce different plants, but make use of similar techniques. A mentioned factor hindering collaboration between growers and suppliers is the inability to find a suitable 
partner. Growers increasingly attach importance to tailored information, which is also reflected in the factors that impede participation in networking activities. The information provided on such activities is often perceived as too general. Paid consultants can respond to this need, but it should be taken into account that they also rely on information from other growers, suppliers, governmental research institutes, etc.

For marketing innovations, horizontal collaboration with colleagues and vertical collaboration with buyers is most frequently observed in this study. Collaboration with other entrepreneurs can be instrumental in gaining insights into tendencies and needs of consumers, which can help with the development of promotional campaigns (Lister 2013). Buyers can usefully support innovators through identifying market opportunities and likely market potential (Pittaway et al. 2004). Buyers can also help to define innovations and, therefore, reduce the risk associated with market introduction (Von Hippel 1988). Cooperating with buyers in the development of innovations is likely to be most common when the market for the innovation is poorly defined (Tether 2002). Marketing innovation is perceived as a much harder process than product innovation. The distrust between colleagues and the fear of losing proper identity are important hindering factors for networking. Also conflicts of interests between partners, a divergent strategic vision and disbelief that collaboration efforts would deliver greater benefits for all chain members are important bottlenecks. A better communication between the actors within the chain can be an important remedial factor.

Regarding organizational innovations, according to our study, a combination of networking with horizontal and vertical networks as well as with third parties seems to have a huge influence on the success of the innovations. This seems to be evident as organizational innovation concerns several domains of the company and hence a lot of decisions have to be made for which knowledge is required and is only present among a variety of partners. Pittaway et al. (2004) also found that more complex innovation processes benefit from engagement with a diverse range of partners which allows for the integration of different knowledge bases, behaviours and habits of thought.

Hindering factors are the high threshold to connect with colleagues from outside the sector and the difficulty to apply the lessons learnt in the own company. Expert consultants, who dispose of the required expertise, can play an important role in stimulating organizational innovation.

\section{Conclusions and implications}

Starting from the premise that the establishment of network relations can provide an avenue to address innovation problems in SMEs and ornamental plant cultivation in particular, the main contribution of this paper is to shed light on the relation between networking and the different types of innovation, and the factors influencing these relations. In contrast to the majority of the innovation studies, which are focusing on technological innovation i.e. product and process innovations (van Galen and Verstegen 2008), this study includes also marketing and organizational innovations.

By looking at the link between innovation type and network partner, we find that network partners differ depending on the innovation type. Furthermore, the qualitative research approach provides unique insights into the factors influencing networking in the 
ornamental plant sector in particular. The results of this study lead to the following research related and managerial implications:

\section{Research related implications}

The present research contributes to the gap in the literature on the relations between networking and the different types of innovation. In the paper, we focus on ornamental plant cultivation in Flanders (Northern Belgium), mainly consisting of micro-sized and family owned businesses, characterized by strong individualism (Van Lierde et al. 2011). Hence, other researchers are encouraged to initiate research on this topic in Europe and the world.

The qualitative research approach enabled us to identify and understand the main factors influencing the relation between networking and type of innovation. In order to quantify the importance of the several influencing factors, future research could benefit from a mixed methods design, where the qualitative approach is complemented with a quantitative approach (Creswell 2003).

\section{Managerial implications}

The findings of this research may have implications for the managers of ornamental plant companies as well as network coordinators in this sector. Our study provides specific insights into the network partners which should be involved for the several types of innovation, and delivers understanding in how influencing factors can be tackled or exploited.

In general, growers could take advantage of the underutilized innovation possibilities through enhanced networking. This would increase the farmers' insights into changing markets and consumer needs and the necessary and relevant partners and information as trigger for innovation. It is important that farmers are aware of the merit of partner suitability for the innovation type they are aiming at.

For network coordinators, it is important to take account of the internal limiting factors of the companies, and to set up a clear strategy and communicate for which innovations their network can advise and help the farmer. Furthermore, network coordinators could focus on improving their approachability and try to increase the added value of activities by aligning them better with the needs of the farmers. They should apply strategies to connect with each other in the most effective and efficient way (e.g. Birley 1985).

\section{Limitations and future research}

Literature about the relationship between networking and the different types of innovation within the agricultural sector is scarce. The present study focuses on the ornamental plant sector in the Flemish region (Northern Belgium) in particular, which has the limitation that the generalizability of the results across other agricultural sectors needs to be carefully considered. The study, however, is providing a starting point for future studies on this topic. Other researchers are hence encouraged to support results of Flanders by investigating the influencing factors of networking for innovation in other agricultural sectors and regions in Europe and the world. 


\section{Authors' contributions}

EL: prepared interview and focus group guides; organized and conducted all the farmer interviews; helped with the organization of and attended focus groups; attended network coordinator interviews; transcribed all the farmer interviews and one of the focus groups. Took the lead in the analysis of the data via NVIVO; drafted the first version of the manuscript; prepared the final manuscript based on comments of all authors. NT: organized focus groups with farmers and network coordinator interviews; transcribed one focus group and the interviews with network coordinators; helped with the analysis of the data. Reworked the manuscript based on comments of other authors. BK: helped with preparation of interview and focus group guides; attended discussion of the codes to use in NVIVO; helped to draft manuscript; revised critically the manuscript (version 1 and version 2). MC: Helped with the preparation of interview and focus group guides; attended discussion of the codes to use in NVIVO; revised critically the manuscript (version 1). XG: gave idea for collection and analysis of data; revised critically the manuscript (version 2). All authors read and approved the final manuscript.

\section{Acknowledgements}

The authors would like to thank the farmers and network coordinators who spent time to participate in the interviews and focus groups and also those who were instrumental in gaining contacts with them. Last but not least, we want to thank the Flemish Agency for Innovation by Science and Technology (IWT 090918) for providing us the possibility to conduct this research.

\section{Author details}

${ }^{1}$ Ghent University, Faculty of Bioscience Engineering, Department of Agricultural Economics, Coupure Links 653, 9000 Ghent, Belgium. ${ }^{2}$ The Institute for Agricultural and Fisheries Research (ILVO), Social Sciences Unit, Burg. Van Gansberghelaan 115, box 2, 9820 Merelbeke, Belgium.

Received: 6 June 2014 Accepted: 5 December 2014

Published online: 22 February 2015

\section{References}

Atuahene-Gima K (1995) An exploratory analysis of the impact of market orientation on new product performance. J Prod Innovat Manag 12:275-293

Bayona C, Garcia-Marco T, Huerta E (2001) Firms' motivations for co-operative R\&D: an empirical analysis of Spanish firms. Research Policy 30:1289-1307

Birkinshaw J, Bessant J, Delbridge R (2007) Finding, forming and performing: Creating networks for discontinuous innovation. Calif Manag Rev 49(3):67-83

Birkinshaw J, Hamel G, Mol MJ (2008) Management innovation. Acad Manage Rev 33(4):825

Birley S (1985) The role of Networks in Entrepreneurial Process. J Bus Venturing 1(1):107-117

Bos-Brouwers HEJ (2010) Corporate Sustainability and Innovation in SMEs: Evidence of Themes and Actitivities in Practice. Bus Strat Environ 19:417-435

Bozeman B (2000) Technology transfer and public policy: a review of research and theory. Research Policy 29(4-5):627-655

Byerlee D, Alex G, Echeverría RG (2002) The evolution of public research systems in developing countries: facing new challenges. In: Byerlee D, Echeverría RG (eds) Agricultural Research Policy in an Era of Privatization. CABI Publishing, Wallingford

Chung S, Kim GM (2003) Performance effects of partnership between manufacturers and suppliers for new product development: the supplier's standpoint. Research Policy 32:587-603

Creswell JW (2003) Research design: Qualitative, quantitative and mixed methods approaches. Sage Publications Inc, Wageningen University Creswell: USA

Crossan MM, Apaydin M (2010) A Multi-Dimensional Framework of Organizational innovation: A Systematic Review of the Literature. J Manag Stud 47(6):1154-1191

Damanpour F, Aravind D (2012) Managerial innovation: Conceptions, Processes, and Antecedents. Manag Organ Rev 8 (2):423-454

De Groot SA (2003) Van OVO naar VOVI: nieuwe institutionele arrangementen voor kennisverwerving en -ontwikkeling van agrarisch ondernemers. LEl, The Hague, The Netherlands

de Man AP, Duysters G (2005) Collaboration and innovation: a review of the effects of mergers, acquisitions and alliances on innovation. Technovation 25 (12):1377-1387. doi:http://dx.doi.org/10.1016/j.technovation.2004.07.021

De Propris L (2002) Types of innovation and inter-firm co-operation. Enterpren Reg Dev 14:337-353

Diederen P, van Meijl H, Wolters A, Bijak K (2003) Innovation Adoption in Agriculture: Innovators, Early Adopters and Laggards. Cahier d'économie et sociologie rurales 67, Wageningen University and Research Centre, Agricultural Economics Research Institute (LEI)

Døving E, Gooderham PN (2008) Dynamic Capabilities as Antecedents of the Scope of Related Diversification: the Case of Small Firm Accountancy Practices. Strat Manag J 29(8):841-857

Fein JA, Lavelle JM, Ginsburg KR, Giardino AP (1997) A methodology to maximize resident input in improving a pediatric rotation. Arch Pediatr Adolesc Med 151(8):840-844

Freel MS, Harrison RT (2006) Innovation and cooperation in the small firm sector: evidence from Northern Britain. Reg Stud 40:289-305

Gellynck X, Kühne B (2008) Innovation and collaboration in traditional food chain networks. J Chain Netw Sci $8(2): 121-129$

Gellynck X, Vermeire B, Viaene J (2007) Innovation in food firms: Contribution of regional networks within the international business context. Enterpren Reg Dev 19(3):209-226, doi:14: Innovation (copy)

Gemünden HG, Ritter T, Heydebreck P (1996) Network configuration and innovation success: An empirical analysis in German high-tech industries. International Journal of Research in Marketing 13 (5):449-462 
Gibb AA (1997) Small firms training and competitiveness: building up the small business as a learning organization. Int Small Bus J 15(3):13-29

Gronum S, Verreyne M-L, Kastelle T (2012) The role of networks in small and medium-sized enterprise innovation and firm performance. J Small Bus Manag 50(2):257-282

Hennink MM (2007) International Focus Group Research: A Handbook for the Health and Social Sciences. Cambridge University Press, New York, Cambridge

Hill J, Wright, T, (2001) A qualitative research agenda for small to medium-sized enterprises, Marketing Intelligence \& Planning, 19(6):432 - 443

Hoffmann WH, Schlosser R (2001) Success factors of strategic alliances in small and medium-sized enterprises - An empirical survey. Long Range plann 34:357-381

Howells J, James AD, Malik K (2004) Sourcing external knowledge: a decision support framework for firms. Int J Technol Manag 9(4):143-154

Katz E, Barandun A (2002) Innovative Approaches to Financing Extension for Agriculture and Natural Resource Management. LBL Swiss Centre for Agricultural Extension, Lindau, Switzerland

Kaufmann A, Tödtling F (2002) How effective is innovation support for SME's? An analysis of the region of upper Austria. Technovation 22(3):147-159

Klerkx L, Aerts N, Leeuwis C (2010) Adaptive management in agricultural innovation systems: The interactions between innovation networks and their environment. Agric Systems 103:390-400

Knudson W, Wysocki A, Champagne J, Peterson HC (2004) Entrepreneurship and innovation in the agri-food system. Am J Agric Econ 86(5):1330-1336

Kühne B, Gellynck X, Weaver RD (2010) Network connections and innovation capacity in traditional agrifood chains. Paper presented at the 116 TH EAAE SEMINAR "Spatial Dynamics in Agri-food Systems: Implications for Sustainability and Consumer Welfare", Parma (Italy)

Lasagni A (2012) How can external relationships enhance innovation in SMEs? New evidence for Europe. J Small Bus Management 20(2):310-339

Lipparini A, Sobrero M (1994) The glue and the pieces: entrepreneurship and innovation in small-firm networks. J Bus Venturing 9:125-140

Lister J (2013) The Importance of Collaborating With Supervisors and Colleagues. http://smallbusiness.chron.com/ importance-collaborating-supervisors-colleagues-33677.html. 2013

Lundvall B-A (1995) National Systems of Innovation: Towards a Theory of Innovation and Interactive Learning. Pinter Publishers, London, UK

Malhotra NK (1999) Marketing Research - An Applied Orientation, 3rd edn. Marketing research - An applied orientation. Prentice Hall Inc., Upper Saddle River, New Jersey, pp 150-160

Mentzer JT, DeWitt W, Keebler JS, Min S, Nix NW, Smith CD (2001) Defining supply chain management. J Bus Logist 22(2): $1-25$

Miotti L, Sachwald F (2003) Co-operative R\&D: why and with whom? An integrated framework of analysis. Research Policy 32:1481-1499

Morris HM, Kocak A, Ozer A (2007) Co-opetition as a small business strategy: implications for performance. J Small Bus Strategy 18(1):35-55

Najib M, Kiminami A (2011) Innovation, co-operation and business performance: some evidence from Indonesian small food processing cluster. J Agribusiness Dev Emerg Economies 1(1):75-96

Nieto MJ, Santamaria L (2007) The importance of diverse collaborative networks for the novelty of product innovation. Technovation 27:367-377

Nieto M, Santamaria L (2010) Technological collaboration: bridging the innovation gap between small and large firms. J Small Bus Manage 48(1):44-69

O'Donnell A, Cummins D (1999) The use of qualitative methods to research networking in SMEs. Qual Market Res 2(2):82-91

OECD/Eurostat (2005), Oslo Manual: Guidelines for Collecting and Interpreting Innovation Data, 3rd Edition, The Measurement of Scientific and Technological Activities, OECD Publishing

Pittaway L, Robertson M, Munir K, Denyer D, Neely A (2004) Networking and innovation: a systematic review of the evidence. Int J Manage Rev 5-6(3-4):137-168, doi:6: Network and Innovation (print out)

Powell R,A, Single H,M (1996) Methodology Matters - V - Focus Groups. Int J Qual Health Care 8(5):499-504

Quintana-Garcia C, Benavides-Velasco CA (2004) Co-operation, competition and innovative behaviour: a panel data of European dedicated biotechnology firms. Technovation 24:927-938

Ritala P, Hurmelinna-Laukkanen P (2012) Incremental and radical innovation in coopetition-the role of absorptive capacity and appropriability. J Prod Innovat Manag 30(1):154-169

Ritter T, Gemünden HG (2003) Network competence: its impact on innovation success and its antecedents. J Bus Res $56: 745-755$

Ritter T, Gemünden HG (2004) The impact of a company's business strategy on its technological competence, network competence and innovation succes. J Bus Res 57:548-556

Robin S, Schubert T (2013) Cooperation with public research institutions and succes in innovations: Evidence from France and Germany. Research Policy 42:149-166

Souder WE, Buisson D, Garrett T (1997) Success through customer-driven new product development: a comparison of US and New Zealand small entrepreneurial high technology firms. J Prod Innovat Manag 14:459-472

Taragola N (2003) Bottlenecks and prospects of the Flemish' cut flower industry (in Dutch). CLE-Publication 1(05):70p

Taragola N, Van Huylenbroeck G, Van Lierde D (2002a) Use of information, product innovation and financial performance on Belgian glasshouse holdings. In: XIIIth IFMA Congress

Taragola N, Van Lierde D, Van Huylenbroeck G (2002b) Factors influencing investments in environmental sound and energy saving technologies by glasshouse growers. Acta Hort 633:35-41

Taragola N, Van Lierde D, Van Huylenbroeck G (2004) Task allocation and human resource management at glasshouse holdings in Flanders. Acta Horticulturae 655:151-115 
Tether BS (2002) Who co-operates for innovation, and why - An empirical analysis. Research Policy 31:947-967 van Galen M, Verstegen J (2008) Innovatie in de agrarische sector: We kunnen er niet genoeg van krijgen! LEI Wageningen, Den Haag

Van Gils A, Zwart P (2004) Knowledge acquisition and learning in Dutch and Belgian SMEs: The role of strategic alliances. Eur Manage J 22(6):685-692

Van Lierde D, Taragola N, Vandenberghe A, Cools A-M (2009) Factors influencing the introduction of reduction techniques for pesticides and nutrients by ornamental plant growers. Acta Horticulturae 831:83-91

Van Lierde D, Taragola N, Saverwyns A (2011) Back to the future - een kritische kijk op vijftig jaar sierteelt in Vlaanderen door bevoorrechte getuigen. ILVO-Mededeling 89:61

Varis M, Littunen H (2010) Types of innovation, sources of information and performance in entrepreneurial SMEs. Eur J Innovation Manage 13(2):128-154

Von Hippel E (1988) Sources of Innovation. Oxford University Press, Oxford

Vorst V (2000) Effective food supply chains: generating, modelling and evaluating supply chain scenarios. PhD thesis, WUR, Wageningen University Creswell: USA

Vuola O, Hameri AP (2006) Mutually benefiting joint innovation process between industry and big-science. Technovation 26:3-12

Whitley R (2002) Developing innovative competences: the role of institutional frameworks. Ind Corp Change 11:497-528

Winch GW, Bianchi C (2006) Drivers and dynamic processes for SMEs going global. J Small Bus Enterprise Dev 13(1):73-88

Zeng SX, Xie XM, Tam CM (2010) Relationship between cooperation networks and innovation performance of SMES. Technovation 30:181-194

\section{Submit your manuscript to a SpringerOpen ${ }^{\circ}$ journal and benefit from:}

- Convenient online submission

- Rigorous peer review

- Immediate publication on acceptance

- Open access: articles freely available online

- High visibility within the field

Retaining the copyright to your article

Submit your next manuscript at $\boldsymbol{\nabla}$ springeropen.com 